\title{
The Impacts \\ Of Institutional Stock Ownership On Stock Returns And Performance: A Financial Market Perspective
}

Johnston Osagie, (E-mail : johnston.osagie@famu.edu), Florida A\& M University Gbolahan Solomon Osho, (E-mail: oshos@uhd.edu), University of Houston-Downtown Cynthia Sutton, (E-mail: cynthiasutton@ prodigy.net), University of Victoria-Cinco Ranch

\begin{abstract}
Recent studies indicate that corporations with high Institutional ownership have higher stock prices than those with less Institutional ownership. Even small companies with high Institutional ownership have higher stock prices in their range. Institutions have researchers and analysts to investigate the financials and the industry potential of the firms. As a result, the perception is that high institutional ownership indicates good value. This study investigates if the percentage of institutional ownership directly correlates with the price of stocks. The relationship between the Institutional ownerships and price was prevalent. This was more indicative among the large cap stocks than the small caps stocks. It was also found that the higher the percentage of Institutional ownership does reflect a higher stock price. This was manifest among the large caps than the small caps.
\end{abstract}

\section{INTRODUCTION}

In the United States, institutions have become the largest shareholders of common stock. Entities such as mutual funds, banks, investment advisors and insurance companies controlled approximately 26.8 percent of market value of publicly traded stock in 1980, up from an estimated 6 percent 50 years ago (Gompers, 2001, Various, 1998). These entities now hold nearly 60 percent of the stock of the 1,000 largest U.S. corporations and are responsible for as much as 70 percent of all trading (Various, 1998, McClure, 2003).

The $\$ 50$ billion a year that institutions spend on research and investment analysts make institutions better, on average, at picking stocks than individuals. (Carnahan, 2002) Institutions combine favored stocks into funds with specific investment objectives. A small investor can purchase shares of those funds that match his investment objectives. However, these funds all have expenses and fees that are charged to the investors. Funds also pass their capital gains to their investors making the individual liable for the taxes. This reduces the returns that shares of stock held in mutual funds generate for the individual investor. This reduction can be eliminated by purchasing stocks directly and holding a portfolio that tracks or mimics the portfolio of a mutual fund or a large asset management company. If the correlation between stock price and institutional ownership is linear, this tracking of an established fund will provide the individual investor with the benefits of professional research.

Recent studies indicate that corporations with high institutional ownership have higher stock prices than those with less institutional ownership. Even small companies with high institutional ownership have higher stock prices in their size range (Ovtcharova 2003). As a result, the perception is that high institutional ownership indicates good value. The objective of this paper is to determine if the percentage of institutional ownership directly correlates with the price of stocks. 


\section{LITERATURE REVIEW}

A review of the literature on the subject of institutional ownership (IO) and stock prices introduces some considerations for the private investor intending to use institutional behavior as a pattern for stock purchases. Recent studies have investigated the effects the changing composition of the ownership profile of firms have on stock prices, the extent to which stock prices reflect future earnings, and the effects that trading have on stock prices (Ovtcharova, 2003, Jiambalvo, 2002, Gompers, 2001, Fang, 20003).

The number of institutions filing Form 13F with the SEC has increased from 525 to 1303 (248percent) from 1998 to 1996 . While 13F institutions controlled 26.8 percent of the market share in 1980, they controlled 51.6 percent in 1996. In December of 1996, the one hundred largest institutions controlled 37.1 percent of the market (Gompers, 2001). Gompers analyzed change in the population profile of management categories assigned by Spectrum from the years 1980 to 1996 and determined that the percentage of banks that report equity holdings declined in absolute terms relative to the number of investment advisors, defined as large brokerage firms. These firms increased by seven times and represented 69.1 percent of the institutions in 1996 . The number of investment companies, representing mutual funds remained relatively stable. Furthermore, several studies (Jiambalvo 2002, Bushee 1998) confirm a median IO percentage of 37 percent of outstanding shares of a firm's stock. Consequently, the motives and incentives of institutional owners have a significant impact on the market.

Articles in the financial press imply that institutional owners are more focused on short-term results (Chote, 1986). This provides an explanation for the sharp changes in market prices from day to day. In particular, stocks held by mutual funds had higher turnover and volatility than those held by individuals (Grabmeier). In a recent study, Bushee (2001) reported a category of investors considered transient who show a strong focus on the shortterm, current period earnings. These managers tend to trade based on herding and it is this behavior that causes the sharp ups and downs of the daily market figures. However, other evidence supports an alternative view of institutional investors as sophisticated managers who use information and analysis to focus on future period earnings.

This alternative view is supported by evidence that current stock prices reflect information on future earnings after controlling for current earnings. In their study in 2002, Jiambalvo, Rajgopal and Vendatachalam demonstrated that institutional investors incorporate non-earnings information, such as long-term sales contracts and expansion plans, in their calculations of a firm's future earnings. This means that current stock prices of firms with high IO are, in part, a reaction to information received in the past as well as a calculation of future value based on information received in the present. Their study also showed that this early incorporation of information increases with increasing percentage of IO. This type of sophisticated analytical behavior explains why price leads earnings when there is high percentage of IO of a firm. This is supported by indications that managers of pension funds are willing to buy and hold stock in firms that have higher R\&D expenses (Hayashi, 2003). The perception is that R\&D investment will increase future earnings.

Evidence shows that institutions have specific requirements for stocks that may differ from an individual investor. As fiduciaries, institutions are bound by 'prudence' (Del Grercio, 1996). This requires institutions to consider variables such as firm age, dividend yield, S\&P membership and volatility when making investment decisions. Institutions are also interested in liquidity and only large cap firms have the size to provide investment opportunities for the considerable funds that institutions control. This need for liquidity pushes the price of large cap stocks up as demand rises while causing a decrease in the price of small cap stocks as demand for their stocks fall (Gompers, 2001).

In their study of 2001, Gompers and Metrick compiled the underlying stocks in the sample mutual fund portfolios into one aggregate portfolio, a giant mutual fund. Statistical models applied to this data indicated that the level of IO at the end of a quarter predicted returns for the next. This appears to conflict with other studies of mutual funds that show them under performing appropriate benchmarks (Jensen, 1969). Gompers and Metrick suggest that this is because their study used raw return data and other studies used returns after fees and transaction 
costs were removed. This indicates that IO does predict returns but the institutions do not earn the expected returns because of fees and transaction costs.

A final consideration for the individual investor is the effect that trading has on stock prices. Cai and Zheng (2003) sorted their sample stocks into portfolios, based on trading volume, at the end of each quarter of the sample period. The stocks with the most intense institutional buying had significant excess returns over the proceeding twelve months. Those stocks that were primarily sold had losses over the preceding twelve months, but these losses were not significant until just before the sample date. The surprising finding was that by the end of the next quarter after portfolio formation the excess returns (losses) had disappeared. This is the expected result if the sample institutions were of the transient type involved in herding behavior. Stocks that have a balanced buy/sell trading volume, showed no significant excess returns or losses. Further analysis of trading habits indicated that banks and insurance companies tend to have less excess funds than mutual funds and the stock traded by banks and insurance companies tend to be less volatile. This tendency toward prudence supports the findings of Jiambalvo, Rajgopal and Vendatachalam (2002) regarding the long-term considerations institutions use to analyze firms.

Ovtcharova (2003) offers a through discussion of the evidence that supports the contention that institutions trade based on fundamentals. She refers to the Nofsinger and Sias (1999) study presents evidence that feedback trading by institutions is primarily restricted to small cap stocks. Institutions tend to base trading of large cap stocks on cash-flow information. This is further evidence of prudence applied to selection of portfolio exhibited by institutions. She used average adjusted returns to show that size is the significant factor in the positive correlation between IO and stock prices. Small stocks showed no significant difference in performance based on IO. These small stocks hold a small portion of the market and their shares are more likely to be closely held or held in blocks meaning that they are less available for purchase by institutions and, therefore, less liquid.

\section{METHODOLOGY}

Institutions make trades in about 75 percent of the stock they own in each quarter (Cai 2003). To keep this paper at a manageable level, the intuitional ownership level used in calculations is that value on March 1, 2003. Stocks were selected using an on line stock screener at the MSN-Money website. A group of stocks that reported a strong price performance over 12 months in comparison to all other stocks was selected along with a group reporting a low price performance over 12 months. The average price of each stock over the past year was calculated using standard Excel formulas. To determine if there was any linear correlation, a scatter graph was charted using IO and average yearly stock price.

Three charts were produced indicating the relationship between IO and price for the entire sample, large cap stocks and small cap stock. To aid comparison, the intercept in each case was set at zero. These charts can be viewed at the end of the study.

Figure 1 shows the relationship between price and IO for the entire sample. This graph shows a general trend toward increased price with increased IO. Figure 2 illustrates the relationship between IO and price in large cap stocks and Figure 3 illustrates the relationship between IO and small cap stocks. The charts support the results of the studies indicating that in general, a higher percentage of IO does reflect a higher stock price. This relationship is stronger in the large cap sample than in the small cap sample with the coefficient for the entire sample falling in between these two. The considerable amount of noise in the samples may be due to the influence of herding on those particular days.

\section{CONCLUSIONS}

There is a correlation between price and IO. The literature indicates that there are variables that contribute to this relationship. An individual investor wishing to use percentage of IO as an indicator must consider the size of the firm. A positive correlation is stronger when the firm has a large market capitalization and is considered liquid by the institutions that hold the majority of the ownership of these large firms. In addition, an assessment of trading history in conjunction with earnings history will indicate which firms' fund analysts believe will do well over the 
long term. Those having balanced buy/sell will provide less risk and more consistent returns. Finally, an investor should consider the types of funds that hold the largest percentage of stock. Banks, insurance companies and mutual funds with a focus on long-term growth will be trading into funds based on their analysts' assessment of future earnings.

Considering the growth in institutional holdings since 1980, it would be interesting to investigate the institutional requirement for large firms in which to invest has fueled an increase in mergers. An additional area for investigation is the possible relationship between the rise in $401(\mathrm{k})$ plans and the increase in institutions.

However, Wallace et al. 2004 noted that stock ownership of directors and managers might also be related to the strengthening of a board and directly impacts market returns. Some empirical studies support these findings. Ghosh and Ruland (1998) find that when target mangers own stock they are more likely to continue employment with combined firm through their ownership to exert influence over negotiations for combined firm governance. Ownership by block holders increases the likelihood of takeovers and could therefore influence the a stock return's performance (Shivdasani 1993).

Figure 1. Price of stock based on percentage of institutional ownership, all stocks

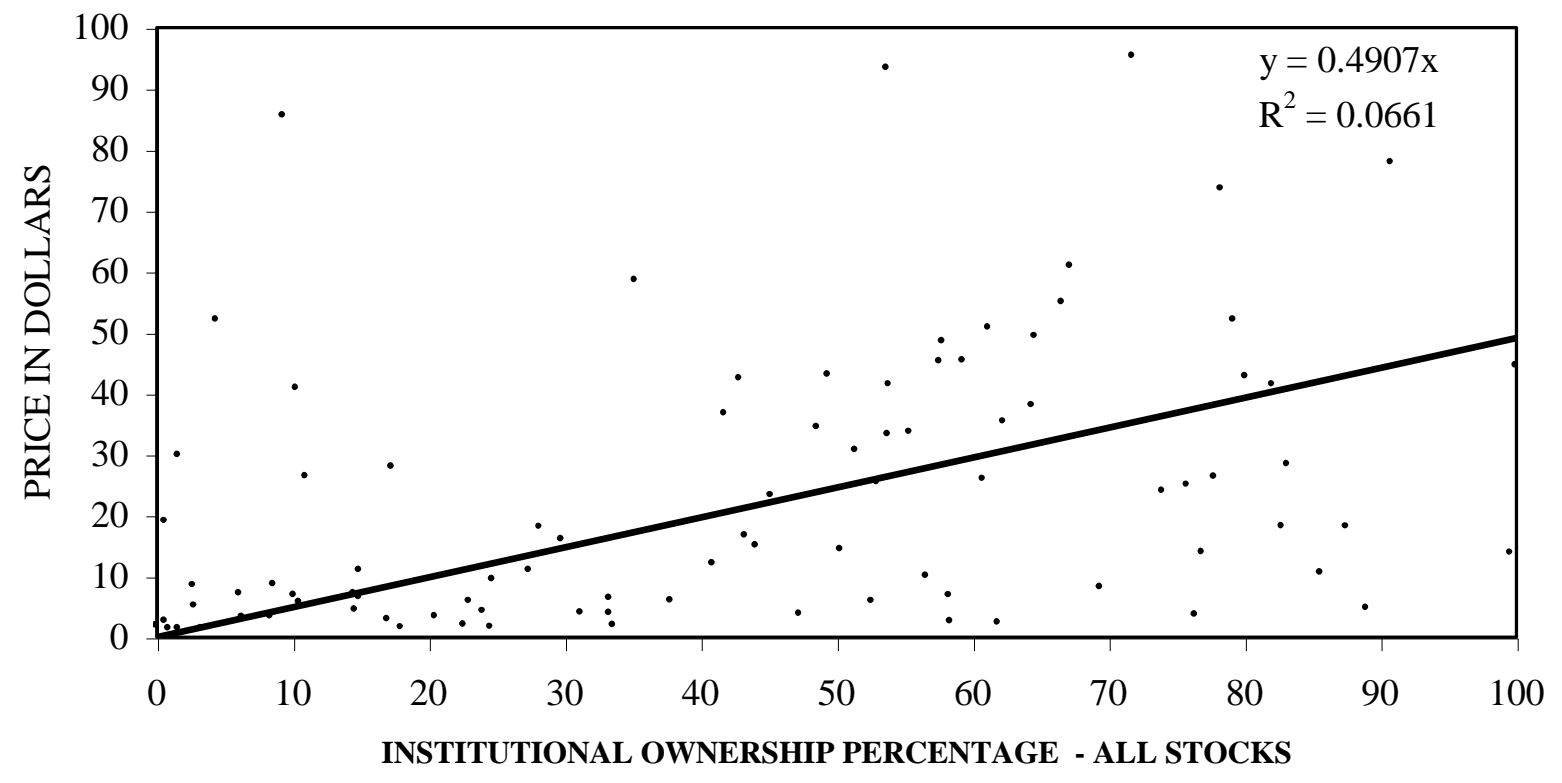


Figure 2. Price of stock based on institutional ownership large cap stocks

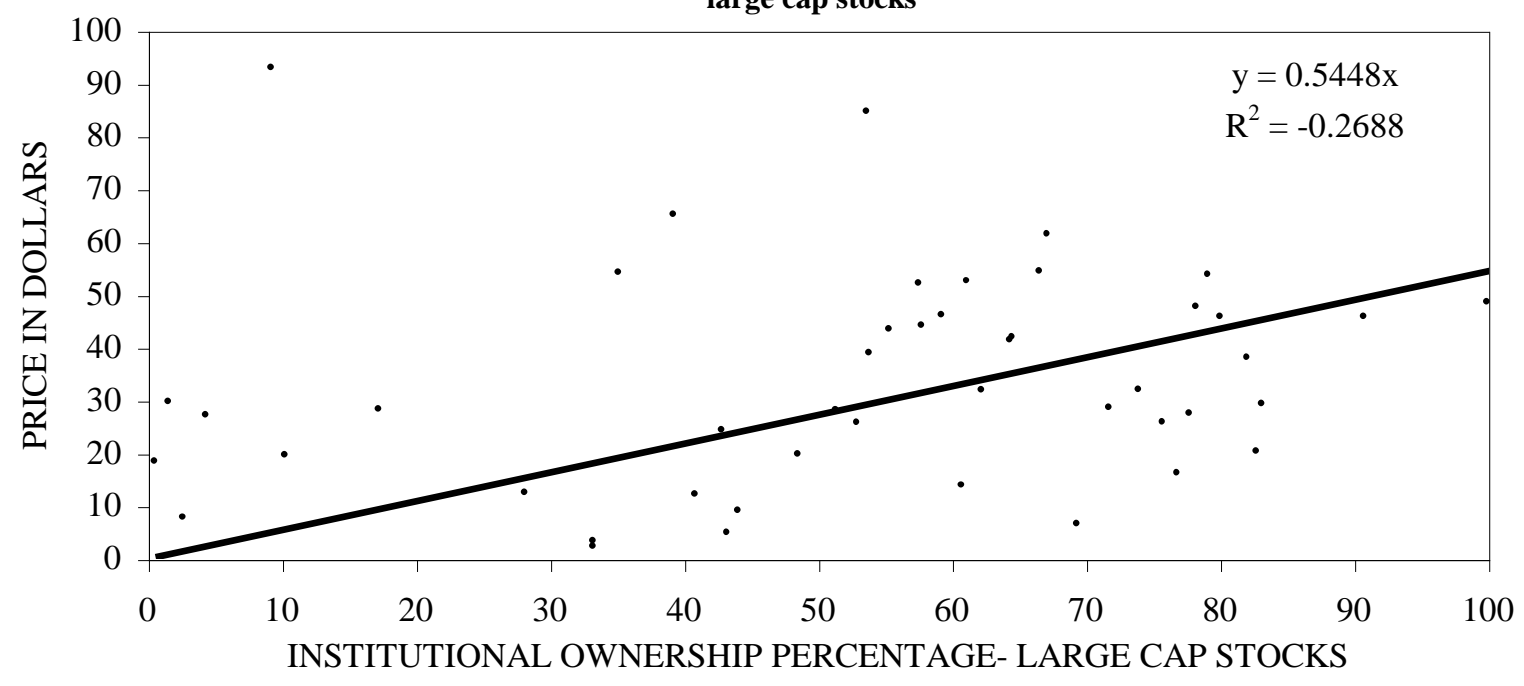

Figure 3. Stock price based on institutional ownership small cap stocks

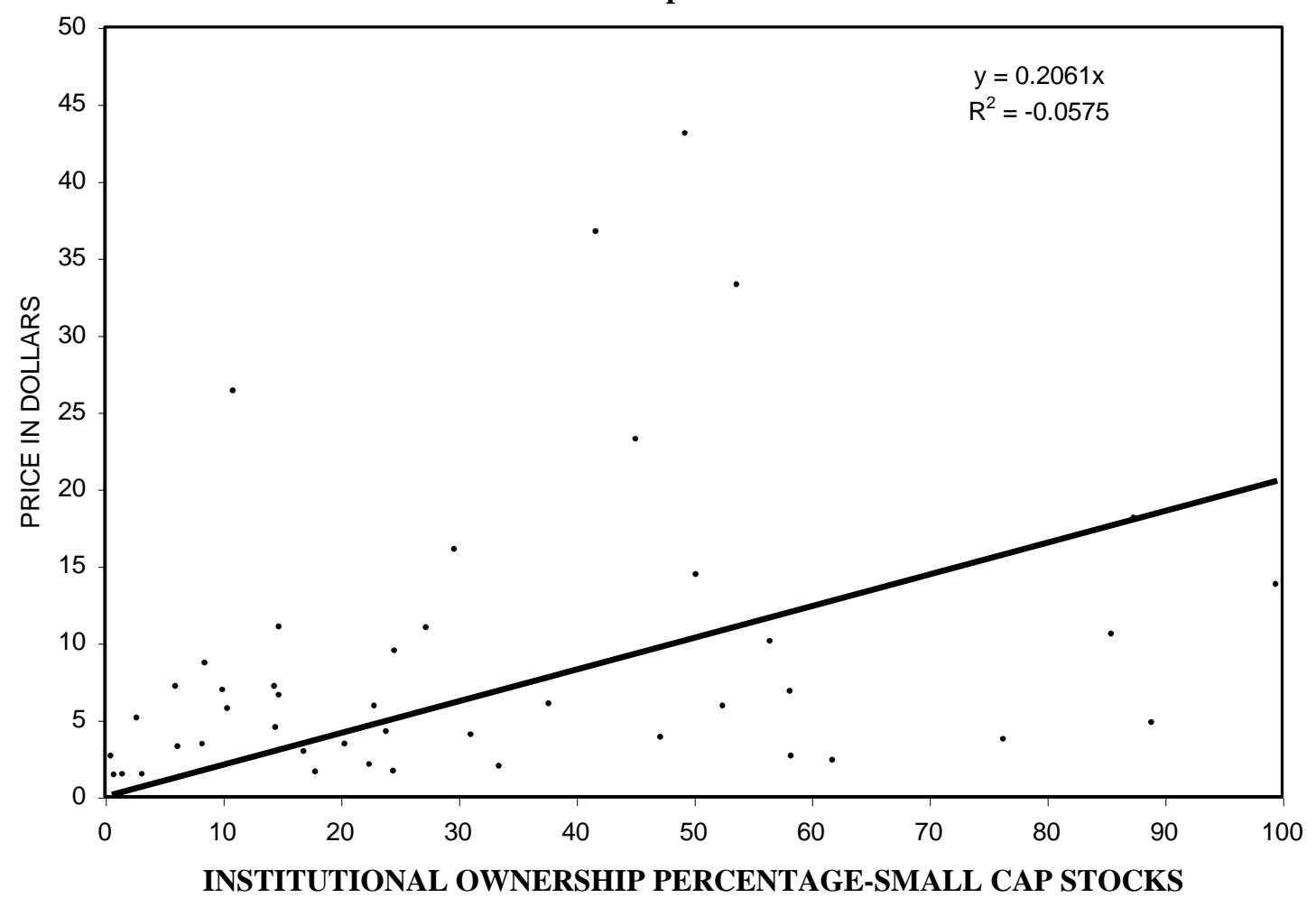




\section{REFERENCES}

1. Bartov, E. S Radhakrishnan, and I. Krinsky, 200. "Investor Sophistication and Patterns in Stock Returns". Accounting Review 75 (1): 43-63

2. Bushee, B. 1998, "Institutional investors, long-term investment, and earnings management". Accounting Review 73 (3): 305-340

3. Carnahan, Ira. "Bet With the Pros" Forbes.com 2.13.02

4. Cai, Fang and Lu Zheng, Institutional Trading and Stock Returns, University of Michigan Business School, February, 2003

5. Chote, P, and J.K. Linger. 1986. "Business and the Short Term Syndrome". Washington Post (June 15): F1F2

6. Del Guercio, Diane, “The Distorting Effect of the Prudent-Man Laws on Institutional Equity Investments", Journal of Financial Economics, XL (1996),31-62

7. Grabmeier, Jeff. "Professional Money Managers Panic Most in Volatile Markets", Ohio State University Research News. 1.31.22 on-line

8. Gompers, Paul A. and Andrew Metrick, “Institutional Investors and Equity Prices”, Quarterly Journal of Economics 116 (1): 229-59

9. Hayashi, Alden M. "Managers of pension funds exert different pressures on a company from those who oversee investment funds". MIT SMR fall 2003. On-line

10. Jensen, Michael C., "The Performance of Mutual Funds in the Period 1945-1964", The Journal of Finance, XXIII (1969), 389-416

11. Jiambalvo, James, Shivaram Rajgopal, and MohanVenkatachalam, "Institutional Ownership and the Extent to which Stock Prices Reflect Future Earnings", Contemporary Accounting Research Vol.19 No. 1 (Spring 2002): 117-45

12. Maranjian, Selena. "Insider and institutional Owners". The Motley Fool 4.17.2002

13. McCLure, Ben, "Institutional Investors and Fundamentals: What's the Link". Investopedia 10/15/2003

14. McDowell, Dagen, "What Short Interest and Institutional Ownership Tell You". TheStreet.com. 8.14.2000

15. Nofsinger, John R. and Richard W. Sias, 1999, "Herding and Feedback Trading by Institutional and Individual Investors", Journal of Finance 54,2263-2295

16. Ovtcharova, Galina, "Institutional Ownership and Long-Term Stock Returns", Working Papers Series, January 2003

17. Various. Financial Economists Roundtable Statement on Institutional Investors and Corporate Governance. 12.1.1998

18. Shivdasani, G. W., 1993, "Board Competition, Ownership Structure, and Takeovers", Journal of Accounting and Economics 16, 167-98

19. Wallace N. Davidson, Samrh S., and Yixi N. "Competition for Board Seats Following Stock-to-Stock Merger" The Journal of Financial Research Vol.27 n1. 2004, 55 pp.

20. "Watch Stocks with High Levels of Institutional Ownership" Investing Guide. On-line 